\title{
Quest for Female Identity in the Novels Bye Bye Black Bird, Fire on the Mountain and Cry the Peacock of Anita Desai
}

\author{
Mrs. Sumitra \\ Research Scholar \\ Department of Humanities \\ Baba Masthnath University \\ Rohtak, India \\ sumitra.rahar@gmail.com
}

\begin{abstract}
The first and foremost aim of this paper is to bring out Identity Quest in Anita Desai's Bye-Bye Blackbird and Fire on the Mountain. In this novel the characters who try to know their self are portrayed accordingly. The Indian novel in English is thus characterized by a variety of themes and techniques. It is changing and developing with the time in Indian environment. Social, Political, Technological and Industrial changes have brought corresponding changes in its substance. However, in the field of characterization the Indian novelist in English has not been quite so successful. With some expectations, his characters continue to be stereotypes. Desai explores the intricate facts of human experience of psychic tensions of her characters. Her chief concern is human relationship. Her theme focused on the relationship of a couple - sensitive wife and ill-mannered husband. This paper attempts to show how they achieve the results they seek to
\end{abstract}


gain in order to expose not only the extremity of the suffering endured by women but also the mental trauma of human beings.

Keywords: Feminism, Role, Rights, exploitation, Awareness, Revolution, Quest, Female Identity, Indian environment, Human beings.

Introduction

This study gives an account of the growth of Indo Anglian Literature. The term "Indo Anglian" was first used to denote the original literary creation in the English language by Indians. Today there are a large number of educated Indians who use English as a medium of creative exploration and expression of their experience of life. Their writing has now developed into a substantial body of literature in its own right and it is that literature which is now referred to as Indian English Literature. Indian began to use English for creative expression much before Macaulay's Minutes on Education (1830) and the implementation of his policy on English education. The novel, the short story and the drama were practically nonexistent in the Indian language before the middle of the century. With the introduction of English in India, there was a spurt of translations, and a number of English Classics were soon translated into various Indian languages, and Indian writers were inspired by these translations. The critics and creative writers in the Indian languages have generally been hostile towards Indo-Anglian fiction. The IndoAnglian writer, on the other hand, enjoys access to a large number of readers both inside and outside India. Indian English literature fiction is compared favorably with the greatest literatures of the world. Now in India particularly within the last three decades a large number of Indian English literature novelists have attracted a great deal of attention and favorable comment. Novelists like Dr. Mulk Raj Anand, R.K. Narayan, Raja Rao, Kamala Markandeya, Mrs. Desai 
and her daughter Kiran Desai have produced novels which have evoked an enthusiastic response from critics inside and outside India. In present scenario Indian writing in English are countless. Besides Mulk Raj Anand, Raja Rao and R.K.Narayan the three foremost Indian writers of fiction in English, there are also K. Nagarajan, Bhabani Bhattacharya, Manohar Malgonkar, Kushwant Singh, Balachandra Raju, Kamala Markandaya and Anita Desai. All these novelists and many more have considerably enriched Indo-Anglian fiction.

The Indian novels made such a late start because, in the beginning, it had to face a number of peculiar problems. One of the most difficult problems that had to be faced was the problem of language. Mulk Raj Anand and Raja Rao have achieved it successfully. Other Indian novelists in English have solved and are trying to solve this problem in their own ways. Another peculiar problem that faces the Indian novelist in English is that of creating an Indian consciousness. The themes of loneliness, rootlessness, the exploration of the psyche and the inner self have been dealt with by Anita Desai, in her two novels, Cry, The Peacock and Voices in the City and by Arun Joshi in his The Foreigner. The term Identity Quest was coined by Erik Emkson the psychologist. It is an important conflict that every human being encounters when he/she goes through eight development stages in life. This is a quality, which everyone emerges to find himself/herself.

Feminism in the Novels of Anita Desai:

The present paper is the result of my hard work and dedication. This paper mainly focuses on feminism in the novels of Anita Desai. Eminent Indian women novelists, Anita Desai is the one who is more interested and more elaborative in her novels. She explains the interior landscape of the mind rather in the politics or socio- political realities. In the novels of Desai, she 
always portrays problems and the sufferings of women in the male dominated society, who have reached different stages in life due to the conservatism of counterparties. Even the women in her novel are fragile introverts rapid in their own skill but these emotional dreams sometimes led to a violent death. Besides that central theme of her novels is the existential predicament of women as an individual. She projects this phenomenon through incompatible couples, in actuality, sensitive and dutiful wives but in sensitive and un-understanding husbands. Her frictional environment is the Indian in transactional which is bound by cultural and ethical values in the melting pot. In each of her novel, one should sense a novelists eager for a way of living, which would respond to the inner most earning of the Indian women for self-emancipation and self-dignity.

Almost in all novels of Anita Desai, she has always tried to convey the inner urges of her female protagonists through her writing and depiction of situation in a proper way that has echoed to all. These things have helped her to peep into the inner world of the women and delineated their reality in totality. She has always acted in her own way and attempted to express the feminism in her own way. She has contributed to the India with the feminist concern; the most important thing about her is the way of expression. Her all novels revolve around men and women of exception, incompatible couples and have always tried to explore the feminism in varied ways She has always covered the women of all age group and all types like children, old, intellectual, dull etc. in her writings which has made her one of the great feminists of the times. Before independence the women were not given the equal status and were getting exploited. But after the independence and introduction of women liberation movement which led to the rise of new women with her own choice, taste and preference and breakage of bands started that had bounded the women and devalued them. Most of the women who are educated grow under selfconflict in terms of marriage, traditional roles. The writers of the post-independence have 
attempted to show the educated women in the present scenario where women's socio-economic conditions have totally changed and they are now revolting against their rights and exploitations. They are now showing better marriage lives and even follow the traditional as well as modern roles in their lives. The current case study on Anita Desai has performed a significant function of instilling a positive "Feminine" identity rather than a female identity, role model women who deters the dependence on men. She has raised voice for the Indian women.

Identity Quest In Bye-Bye Black Bird:

Writing novels about one's own country on the basis of memory have been a great challenge for a number of exiled or immigrant writers. Anita Desai is a powerful and persuasive voice among the Indian novelists who cut off from their ethnic roots. A close study of Desai's works reveals her struggle for female autonomy played out against the backdrop of the patriarchal cultural pattern. In Bye Bye Blackbird Anita Desai deviates from her earlier theme of the treatment of the psychic tumult of her self-afflicted characters. In this novel she deals with the tropical problem of adjustment faced by black immigrants in England. She raises this problem portraying the situations of three different characters Dev, Adit and Sarah by exploring the effect of racial hatred on their sensibility. To sum up, all the three leading characters in Anita Desai's novel face identity Quest. It is self-alienation of these characters that is brought to focus in the novel. The characters, we find, are forced to manipulate in accordance with the social demands. Desai places her characters in certain delicate human situations and they embark on self-analysis. They make self-discovery and very often find themselves alienated. Many a time they travel through a world of fantasy in order to come to terms with the reality of the situations. Adit's nostalgia acquires a dreadful dimension of an illness, an ache in him. It begins, it 
suffocates then it makes him to feel fed up with the life in England. He admits to his friend "sometimes it stifles me this business of always hanging together with people like ourselves all wearing the label Indian immigrant, never daring to try and make contact outside this circle," he is himself like an existentialist. He comes top and considers himself a stranger. He moves about in London in a kind of morbid, search for belonging but London appears to be altogether different: he simply could not recognize his workday, weary London as his once- golden Mecca. He took to trumping it after office hours in a kind of morbid search. Ultimately Adit decides to return to India with his wife Sarah. The Quest of identity among the major characters lasts longer and they are not in a position to take immediate decision as what to do.

\section{Quest for Anita Desai's 'Cry the Peacock:}

The women portrayal in the literature is changed from the past. Women writers have strayed from traditional portrayals of enduring, self-sacrificing woman and have presented strong female characters searching for an identity of their own. They no longer typify and define women simply in terms of their victim status. A major preoccupation in recent Indian women's writing has been a de-alienation of inner life and subtle interpersonal relationships. Indian women writers have started questioning the high up old patriarchal domination. They are no longer puppets in the hands of men. They have proved themselves on the pitch of literature both qualitatively and quantitatively. Many Indian women writers have explored female subjectivity in order to establish an identity of their own. Anita Desai is unquestionably one of the celebrated Indian- English fiction writers. She holds a distinguished place among the women novelists of India. Anita Desai's women characters in her novels rebel against patriarchal community in order to explore their own potential (identity), to live life on their terms, regardless of the outcome that 
such a rebel may have on their lives. Her characters criticize cultural ideologies of the society and declare their self- proclaimed freedom. Desai explores the human psyche. She is endowed with searching psychological insights and peeps into the inner recesses of the psyche, rather than just presenting the outer spectacle of the world. Cry, the Peacock her first novel has been considered to be a pacesetter in the field of psychoanalytical realism. It explores the inner world of the main protagonist Maya, and demonstrates her fear, insecurity and strange behavior. Through Maya's character, Desai depicts a world of alienation, loneliness and suffering.

In the novel, Cry, the Peacock Maya, the female protagonist has been brought up under the excessive love, care and concern of her father. This excessive love on her father's part makes her behave abnormally in her later life. Maya's sorrow begins quite early in life with her marriage to Gautama, a middle- aged lawyer, and a protégé of her father. There is a vast difference in their ages that contribute to further conflicts between the two. Gautama's insensitive behavior towards Maya makes her feel lonely, isolated, neglected and aggravated. She expects a little more attention from Gautama as her father showered on her. In short, Maya wants Gautama to be her father- figure. She wants Gautama to not only take care of her childish needs but also always protect her from the outside world. Quite contrary to her expectations, Gautama is preoccupied with his work and doesn't have a few moments to spare for his wife.

Desai prefers to explore the private to the public world. Her real concern is the exploration of the human psyche, inner climate and she unravels the mystery of the inner life of her characters like that of Maya. Desai's female protagonists are alienated from the world, society and family because they think of themselves as individuals. Her characters are selfcentered who want to change either the situation or things around themselves. Needless to say they are hardly able to bring about that change in their lives and end up being lonely and 
dejected. When alienation is forced on such characters they become rebels. Tensions, worries, depression, disappointment, anxiety and fear become their lot and they lose their sense of sanity. Desai's female characters project the battles that are fought and those left unsought. The psychological battle is fought against traditionally defined womanless. The psychological suffering of finding themselves and their identity along with the pressures felt by women to fulfill the demands placed by the so- called ideal concept of womanhood culminates in withdrawal, regression, neurosis and suicide mania.

Identity Quest in Fire on the Mountain:

A highly imaginative work of literature would always offer diverse interpretations, as regards to its purport, by a critical reader. And Anita Desai's novel Fire on the Mountain too belongs to such a category. It is one of the few examples in Indo- Anglian fiction which succeeds in sustaining the readability despite any attempt to bring in much of either the fascinating or shocking elements in the narrative. Throughout the novel there is very little action and most of the narrative encompasses the minute details of the surroundings in the form of birds, trees, sounds, landscape etc. But the writer, it seems, has the factor of human relationship to be focused in its myriad manifestations within the range of the few main characters involved in the story. This article is an attempt to examine the intricacies of the nature and extent of the attitude and relationship among these characters Fire on the Mountain,, is the story of three female characters who live in a Cocoon like existence in the Shimla hills of Kasauli There is Nanda Kaul, her fragile recalcitrant great granddaughter, Raka and her childhood friend Ila Das. Though all the three have interest on a physical plane yet they live in separate worlds of their own.They make feeble attempts to build bridges of understanding among themselves but cannot go too far. Each 
has a separate individuality. Each wants to be left undisturbed.The great need of Nanda Kaul is exactly what Nanda's daughter Asha fails to realize. She takes for granted her mother's delight at a prospective companion. Nanda struggles hard to suppress her anger, disappointment and total loathing of her daughter's meddling busybody ways. Nanda Kaul does not want to be drawn into the world. She has left behind, to bow again, to let the noose slip. Once more round her neck that she had thought was freed fully. She silently questions herself at this threat to her freedom, her heart cries out.

"Have I not done enough and had enough. I want no more. I want nothing. Can I not be left with nothing?"

At the end of the novel, Anita Desai comes to such that stage Raka has bolted towards the forest with a box of matches. Here it is irresistible to compare a parallel situation in a poem. Sahir Ludhianavi, an Urdu poet, makes the protagonist of his poem, a sensitive poet having long suffered at the hands of the stronger and "prestigious" members of the society, crosses the limits of tolerance for false traditions, sham friendship and disloyalty and he explodes with; Jala Do Ise Hosh Whlo Yeh Duniya! (Men with reason! Burn down this world). The same statement is endorsed by Anita Desai through the seemingly puzzling last act of Raka. The Quest in human values is highlighted by Anita Desai in the blatant way, Nanda's husband, the Vice-chancellor of Punjab university is totally uncaring about his wife's feelings. He merely used her as a necessary adjunct to his status, keeping her respondent in silks and Jewels. He would make her sit at the big rosewood table entertaining his guests. This anguish works at the sub-conscious level. For the final act of Raka, a compact metaphor takes shape. The proud and tall trees forest on the hills look down upon the humble earth like the transgressing male. Raka, however, gets hold of an image and has the temerity to act boldly.. She burns them down. The trees would revert back to 
the earth rendered into ashes to the earth from where they had originated and obtained sustenance. The ashes would then bring a sense of equality and mutual respect. The woman of future -the child Raka -offers the message of Anita Desai to the next generation whose mothers, sisters and daughters had so far been subjected to gross organized injustice and exploitation as they considered themselves too weak to resist the male offenders.

\section{Conclusion}

Anita Desai's novels are pre-occupied with the inner feelings of the characters. Most of his characters undergo severe psychological feelings which in the end profess something unexpected and even unpredictable. Anita Desai was rightly called the Indian Virginia Woolf for she introduced the stream of consciousness' technique in Indian soil. In the novels Bye Bye Blackbird and Fire on the Mountain the protagonists Adit and Nanda Kaul undergo serious psychological feelings, which ultimately results in the identity Quest of the same. Both the characters are not satisfied with their state of being. This is because they had been forced to such. The women in Desai's novels are stilled to silence. They go through the amorphous existences with sealed lips groaning inwardly with self-pity and pain. The portrayal of human relationships husband and wife, parent and children, is a dominant concern in Desai's novels. The husbandwife relationship is sour and disgusting. Desai's protagonists turn the whole face of romance upside down.

Desai's characters, Maya, Monisha, Nanda, and Sita are quite dissatisfied in their matrimonial relationships. Desai's women face tension on account of the tensions generated by the discord between the individual and the surroundings. Sita cannot adjust to the violence and other harsh realities of life. In Anita Desai's novels woman who lies or who is silent may not 
lack a language but she does not communicate. Desai's women often fail to communicate and resort to silence. A silence which is often misunderstood by men as the symbol of contentment. Cry, the Peacock is a novel mainly concerned with the theme of marital disharmony between husband and wife. This novel's theme of which may be described as an incompatible marriage with the focus on the heroine's psyche. Her second novel Voices in the City is a novel about a family and the influence of the city of Calcutta on the three characters of the family, namely, Nirode, Monisha and Amla. Desai's novels are not sociological phenomenon's rather it is psyche. She raises the voices of mutes and helpless married women. These women are tormented by existentialist problems and predicaments. Desai reveals a rare imaginative awareness of various deeper forces at work and finds a profound understanding of work and finds a profound understanding of women sensibility. 


\section{References}

Desai, Anita. Cry, the Peacock, New Delhi; Orient PAPERBACKS, 1995. Print

Jebaselvi, Alice Evangaline. A Psychological Cry of an Alienated Woman: Anita Desai's Cry, the Peacock. India; April 2014. Print

Bhatnagar. K Manmohan and Rajeshwar. M. THE NOVELS OF ANITA DESAI: A CRITICAL CASE. New Delhi: ATLANTIC PUBLISHERS, 2008.

Presad, Amarnathand Paul S. K. Feminism In Indian Writing In English. New Delhi: SarupAnd Sons Publishers, 2006.

Singh R. A. Three Novels of Anita Desai A Critical Spectrum. New Delhi: Book Enclave Publishers, 2009

Desai, Anita. Where Shell We Go This Summer: Orient Paperbacks Publishers, 2005

Baanerjee, Uma, An Existential Approach to Malaadjustment of Marital Relations in Anita Desai’s Novels, Indian Women Novelists Set I, Vol.II, Dhawan R.K. (e.d) New Delhi: Prestige Books 1991.

Bala, Suman, D.K. Pabby The Fiction of Anita Desai, Vol.1 New Delhi: Khosla Publishing House, 2002.

Bhatnagar, Manmohan K. and Rajeswar M. The Novels of Anita Desai: A Critical Study, New Delhi: Atlantic Publishers and Distributor, 2002.

Iyengar Srinivasa K.R., Indian Writing in English, New Delhi: Sterling, 1996. 